\title{
An Investigation into Students' Preference of Instructional Methods used in Teaching and Learning of Social Studies
}

\author{
Oyibe, Ogene A. \\ Email: buikeoyibe@gmail.com \\ Ven. S.C. Nnamani Ph.D \\ Arts \& Social Science Education \\ Ebonyi State University, Abakaliki \\ Email: symonchiji@gmail.com
}

Arts \& Social Science Education, Ebonyi State University, Abakaliki

\begin{abstract}
Doi:10.5296/ijld.v5i1.6890
URL: http://dx.doi.org/10.5296/ijld.v5i1.6890

\section{Abstract}

The thrust of this paper was on investigating students' preference of instructional methods used in teaching and learning of Social studies in secondary schools in Abakaliki metropolis of Ebonyi State, Nigeria. Though, there have been several researches conducted by other researchers geared towards questioning the effectiveness of instructional methods in achieving the programme and instructional objectives of Social studies but many of these researches have failed to put into consideration 'which method (s)' did students prefer in Social studies classroom interaction. It was on this note that the research of this nature was conducted to determine students preference of instructional methods used in Social studies pedagogy. The researchers employed descriptive survey research design aimed at eliciting information from the respondents based on one research question that guided the study. The population of the study comprised of three hundred and seventy-four (374) JSS II students drawn from nine (9) governments owned secondary schools in the study area. Questionnaire was used as an instrument for data collection and data were analyzed using simple percentage. The findings of the study revealed that students prefered instructional methods that involve active participation of students in teaching and learning of Social studies. The findings also revealed that most teachers rely more concentional note-taking methods as only instructional methods for classroom interaction. It is based on these findings that the researchers recommended that government and other bodies in educational industry should organize workshops for teachers on indispensabilities of instructional methods to achieveing instructioal objectives of Social studies.
\end{abstract}

\section{INTRODUCTION}

One of the challenges for Social studies teachers in Nigerian educational system is to meet the individual needs of students in a classroom setting characterized by multiple levels of ability, skills, attitudes, behaviours, interest, emotion, social and physical development. Undoubtably, one can agree with me that it is no longer a news in Nigeria that regular classroom interaction of curriculum subjects like Social studies do have students from diverse cultural background with multiple levels of interest, emotion, ability, skills and attitudes to learn which demands that classroom teachers of Social studies should increase their time and efforts in order to make classroom interaction more interesting and lively. This probably informed the view of Awe in Fadieye (2005:6) who held that, "...Social studies is a discipline if properly programmed and effectively tought should help to solve social problems that are 
facing developing countries like ours (Nigeria) where the old norms are fast loosing their grips and without any effective substitute to replace them". This implies that if teacher in classrrom effectivley teach Social studies curriculum content, it will instill in the students inquiring spirit that will bring about development of values in their own learning. No wonder, mbakwem (2005:163) was of the view that Social studies focuses on

Skill acquisition and development of values, effective values and learning outcome which demands that the subject should be properly taught so as to equip the studnets with such skills as locating information from print media, textbooks, libraries, newspapers, as well as from resource person and community resources.

Lending support to the above statement, Jarolimek (1977:3) maintained that, Social studies is expected to contribute in measurably to the development of confidence, hope and positively self image in our children in conflicting ideologies, valves and attitudes since it aims at:

helping young people develop competence that enables them to deal

with and to some extent manage the physcial and social forces of the world in which they live. It also provides young people with a feeling of hope in the future and confidence in their ability to solve social problems.

Considering the importance of Social studies as discursed above, Adeniji (2004) suggested that teachers of Social studies at all level of education need to be farmiliar with the content and methods of teaching the subject in order to interpret the content of Social studies correctly and encourage its learning. This is mainly because when Social studies instructional methods are related to the content, learning will cease to be fragmentary and memorization of unrelated facts and concepts will end. It is only when Social studies content is related to instructional methods that students will be able to appreicate the importance of Social studies and pass valide judgement of what Social studies is.

Unfortnately, at present students often consider Social studies to be dull and buring, (Chiodo and Byford, 2006). Not only do students percieved Social studies to be dull,but they also fail to see nothing good of Social studies in their every day living. One may ask, why all these? The simple answer to that questions is either that the content of Social studies is boring, dull and uninteresting or that the instructional methods used by teachers in Social studies classroom interaction do not either inspire or engage the students actively in learning Social studies concepts. Therefore, Social studies as an inter-discipline subject should be taught with a wide spectrum of instructional methods that will enhance active participation of students in the teaching and learning process. It is only when Social studies instructional activities are dominated by the students that they will be able to think critically about their own assumptions and about the world they live, so that they will no longer be contended to accept their lot blindly but can learn ways of contributing towards changes. Ikwumelu (2002) noted that at present, social awareness and social understanding in Social studies are still to be developed, students still consider either to take for granted what their teachers offers or reject it out of hand probably as a result of wrongly application of instructional methods by Social studies teachers in teaching and learning processes. According to Shaughnessy and Haladyna (1985), it is the teachers who is the key to what Social studies will be for the students. Instruction tends to be dominated by the lecture, textbook or assignment... and Social studies does not inspire students to learn. Siler (1998) explained that teachers tend to use only one teaching style day after day, which denies students the opportunity of a variety of teaching methods. Explaining further, Ellis, Fouts and Glenn (1992) stated that teachers often rely solely on lecture method, assignment and traditional tests as methods of teaching and learning. However, researches findings have revealed that students have more interest in a topic when a variety of teaching 
methods are implemented (Slavin, 1994; Byford and Russell, 2006 and Chiode and Russell, 2006).

The ability to use various instructional methods for classroom interactions is often neglected by educators thereby hindering effective implementation of Social studies curriculum content. Teachers tend to have students participate in instructional activities that do not encourage critical thinking but instead encourage rote memorization of names, dates, and places. In addition, Vansladright (2004:233) explained the common preoccupation with having students history textbook recitations and lecture method does little to build capacity to think historically. In the same vain, Hongland (2000) observed that teachers need to connect the content to the individual interest of the students, thus increasing students' interest in the content and achively engaging studentes in the learning process. This implies application of a variety instructional methods that help engage students in the learning process. Some examples of engaing instructional methods includes self-directed learning, cooperative learning, role playing, and technology (Driscoll, 2005). Many educator (Borich, 2011, and Teo, 2006) supporting the effectiveness of self-directed learning strategy is the method in teaching and learning situations which involves getting students to unleash their imaginative and intuitive capacities throught learning. Therefore, self-directed learning strategy is capable of promoting maximum interaction between and among social studies students to enhance efficient decision making while discussing and analyzing social issue. Teo (2006) thus asserted that self-directed learning strategy involves students in making connections between new and already known ideas or facts, engaging in dialoques in which hypotheses are formed, predictions are made, doubt expressed, uncertainities subsequently clarified and the orthodox/traditional view modified by new ideas.

Cooperative learning strategy is the instructional technique use for small group in which pupils students work together to maximize and gain from each other. Slavin (1995) was of the view that in cooperative learning strategy, students are expected to help, discuss and argue with each other; asses each others' current knowledge; and fill any gaps in each others' understanding. In the same line of though, Stahl (1994) believed that cooperative learning strategy provides opportunities for students to learn, practices and live the attitudes and behaviour that reflect the goals of social studies education. He then explained that using cooperative learning strategy requires students to become active learners. Application of various instructional method can only be used to achieve some specific objectives, others can achieve multiple objectives simultaneously. A method which fails with one students may be very helpful to another, so the teacher may need to employ several methods during a single lesson. Ikwumelu \& Oyibe (2011) stated that utilization of individualized instructional method in teaching and learning of Social studies provide the opportunity for the students to learn at their own pace and their own way, and be succesful. Ikwumelu (2002) concluded that use of dramatization, concept mapping, simulation, group discussion and computer games are all best ways to provide students with one information. Using computer games to promote teaching and learning of social studies has been found to be in effective and reliable instructional method (Senesh, 2002; Ikwumelu and Oyibe, 2011). In 2013 researchers conduced that using questioning method hightened students interest and promote understanding (Oyibe and Mbang, 2013). Again, Bozimo and Ikwumelu (2009) were of the view that group discussion method is valueable method for Social studies instruction.

In 2011, researchers found out that $78 \%$ of Social studies teachers in secondary schools in Ebonyi State use lecture method as the only means of passing information to the students (Ikwumelu and Oyibe, 2011). In addition, Ruseel and Byford (2006) stated that 85\% of the 8th grade teachers who participated in the study $(n=350)$ used whole class presentation (lecture) as a method of instruction. In support of the above, leming, Ellington and Schug (2006) opined that $64 \%$ of teachers had students read in textbooks and $54 \%$ had students complete assignment 
as part of class instructional activities. These data unfortunately signified that teachers utilized only lecture-based instructional methods in teaching and learning of Social studies and non-engaging activities despite the numerous research findings to that effect. The thrust of this paper to find out the what student liked and disliked in social studies instruction.

\section{Research Question}

One research question was designed by the researchers that guided the conduct of this study. The question is:

- What instructional method(s) would secondary school students prefer in teaching and learning Social studies?

\section{Methodology}

The design of this study was decriptive survey research design. Descriptive survey research design aimed at collecting data from the respondents without mainpulating any variable (Ali, 1996). The study was conducted in Abakaliki metropolis of Ebonyi State and the population of the study comprises three hundred seventy-four (374) junior secondary school two (JSS II) drawn from nine(9) government owned secondary schools in Abakaliki metropolis. The names and percentage of the population of each school are underlisted thus; government technical college, Abakaliki had 10.96\%; Abakaliki High School (Presco) had 11.76\%; Girls High School, Abakaliki had 12.29\% Command Secondary School, Abakaliki had 13.10\%; Urban Secondary School, Abakaliki had 12.83\%; Army Day Secondary School, Abakaliki had 11.22\%; Modern Girls Secondary School, Ugwuchara had 13.90\%; Prisons' Secondary School, Abakaliki had 4.03\% and Izzi High School, Abakaliki had 9.91\% of the total population of the study. The instrument used for data collection was structured questionnarie and data were analyzed using simple percentage. The method that rated $50 \%$ (percentage) and above is judged highly preferred and method that rated below $50 \%$ (percentage) was judged low preferred.

\section{Results}

Mean rating of students' preference of Instructional Methods for teaching and Learning Social studies

\section{Learners-Centered Instructional Methods}

$55 \%$ of the students prefered Inquiry method

$76 \%$ of the students prefered Games and Simulation method

$46 \%$ of the students prefered Project method

$63 \%$ of the students prefered Group discussion method

$92 \%$ of the students prefered Self-directed method

$89 \%$ of the students prefered Cooperative method

$87 \%$ of the students prefered Individualized method

$69 \%$ of the students prefered Computer gamme method

$48 \%$ of the students prefered Dramatization method

2. Teacher-Centered Instructional Methods

$39 \%$ of the students prefered Lecture method

$11 \%$ of the students prefered Note-taking method

$23 \%$ of the students prefered Story-telling method

$32 \%$ of the students prefered Demonstration method

$35 \%$ of the students prefered Explanation method

$10 \%$ of the students prefered Expository method

$15 \%$ of the students prefered Questioning method 


\section{Discussion}

The results of data analysis presented above revealed that secondary school students prefered learning Social studies with multiple instructional methods. More especially, methods that involve active participation of students in the teaching and learning processes. This implies therefore that, teaching and learning Social studies with combination of multiple instructional methods make classroom more interesting and achievement of the programme and instructional objectives are more certain. Agreeing the above findings, Woolfolk (2010) was of the view that much of today's classroom teaching and learning should focused on activities which will lead the students acquire facts, rules, and action sequences. He also regrated that majority of the lessons given to students in schools require outcomes only at the lower levels of cognition: knowledge, comprehension and application. This explained why some national studies of the state of education in the United States of America (USA) and Nigeria, for instance; (American Association for the Advancement of Science, 1996, 2005; National Council for Social Studies, 2002, 2006. Then the Nigeria national studies like, National Council of Teachers of English, 1996, 2006; National Council of Teachers of Mathematics, 2000, 2005) found many students unable to think independently of the teacher or to go beyond the content in their text and workbooks. These studies suggested that the manner to which most schooling occurs could not be teaching students to become aware of their own learning, to think critically, and derive their own patterns of thought and meaning from the content presented, as suggested by the cognitive outcomes, (Borich, 2011).

Further more, Chiode and Russell (2006) noted that students have more interest in a topic when a variety of teaching methods are implemetned. Owing to this fact, it is pertinent to note that this research work revealed that teaching and learning Social studies with combination of multiple instructional methods makes classroom more interacting and lively. This is in line with the views of (Driscoll, 2005; Russell and Byford, 2006) who concluded that application of multiple instructional methods such as self-directed learning strategy, cooperative learning strategy, role-playing, computer game, concept-mapping, and creative activity method. Borich (2011:328) opined that "self-directed instructional method is the method used in teaching and learning situations which involves getting students to unleash their imaginative and intuitive capacities through learning". He then outlined the reasons for the application of the self-directed instructional method in the teaching and learning situations to include;

i. To get students to unleash their imaginative and intuitive capacities through self-directed learning.

ii. To get students to accept responsibility for their own learning.

iii. To teach students to go beyond the content given, to think critically, reason and problem solving.

iv. To engage students in project-based learning strategy and

v. To promote the goals of self-directed learning using differentiated instruction.

Teo (2006) added that, self-directed instructional method involves students in making connections between new and already known ideas or facts, engaging in dialogues in which hypotheses are formed, predictions are made, doubt expressed, uncertainties subsequently clarified and the orthodox/traditional views modified by new ideas. Self-directed instructional method promotes maximum interaction between and among Social studies students to enhance efficient decision making while discussing and analyzing social issues. The method encourages the development of critical thinking through discussion, negotiations and clarifications of basic content or ideas because in self-directed learning, students enjoy the liberty to advance their own ideas and to benefit from the ideas and views of others.

Again, cooperative learning involves a small group of learners working together as a team to solve a problem, complete task or accomplish a common goal. Cooperative learning 
method is a method that relies on the philosophy that knowledge is essentially social in nature. Learning is a social activity where learners interact with others through communication and cooperative effect. In the same line of though, Stahl (1994) believed that cooperative learning strategy provides opportunities for students to learn, practices and live the attitudes and behaviour that reflect the goals of Social studies education. He then explained that using cooperative learning strategy requires students to become active learners. Kelly and Farman (1990:34) highlighting the benefits of cooperative teaching and learning strategy in the teaching and learning of Social studies in school held that:

* Cooperative teaching and learning strategy enhances the development of critical thinking through discussion, negotiations, and clarification of ideas.

* Students enjoy the liberty to advance their own ideas and benefit from the ideas of others.

* It involves students in making connections between new and known information.

* It helps students to develop good social interaction skills.

* It promotes academic achievement

On the other hand, Mbakwem (2001) opined that individualized instruction is an instructional mode that is tailored to the need and ability of individual learners. It is an individual-oriented method which seeks to identify the needs of individual, be it physical, social, emotional or intellectual. Individualized instruction means giving suitable instruction to each student. It is not teacher-centered, and different students-centered and the purpose is helping students learn what they need using their own learning style and at their own pace. The use of individualized instruction in teaching Social studies in secondary schools enables the teachers to see each learner as a unique being that possesses certain peculiar traits, potentials, and abilities. Therefore, it is expected that the teacher should ensure that the unique qualities are carefully put into consideration in the teaching and learning processes.

The findings of the study revealed that the respondents showed low preferences to conventional methods of teaching Social studies. From the responses of the respondents, the researchers observed that conventional methods like lecture method, note-taking method, story-telling method, guestioning, explanation and expository methods make Social studies classroom instruction passive. Therefore the methods do not actively involve students in the teaching and business. According to Ikwumelu and Oyibe (2011), lecture method of teaching is a discourse given before an audience upon a given subject, usually for the purpose of instruction. Aguokogbuo (2000) explained that lecture method is a method that can aptly be described as a teacher-centered because the lecturer determines the pace and tempo of the lecture. Bozimo and Ikwumelu (2009) concluded that lecture method does not provide opportunity for students to interact with the teacher during the lecture and makes the learning process passive, bring on the part of the students lesson instead of active.

\section{Conclusion}

The findings of the study have revealed that students prefered application of learner-centered instructional methods in the teaching and learning of Social studies and that application of conventional instructional methods in teaching and learning of Social studies make classroom interaction passive and unintersting. Therefore, application of conventional methods affects actualization of the objectives of Social studies. It is the researchers' opinion that if teachers apply methods like concept map, cooperative, self-directed,dramatization and group discussion methods in delivering classroom instruction, poor attitudes display to Social studies by students will stop and it will help in improving the academic achievement of Social studies students. 


\section{Recommentions}

Based on the findings of the study, the reseachers recommended that:

* Government and ministry of education should organize seminars/workshop to train teachers on the relevance of uses of learner-centered methods in Social studies education.

* Competent and qualified teachers who as versed in Social studies content and methods should be employed as a matter of urgency in secondary schools.

* Teachers on their own should learn to select and use appropriate instructional methods that will actively involve students in the teaching and learning business as such are the way of improving students' reflective thinking and encourage learning.

\section{References}

Adeniji, A.O. (2004). Social studies Teachers and instructional Techniques in Nigeria Secondary Schools. Ago-Woye: Pymonak printing and publishing Co.

Aguokogbuo, C.N. (2000). Curriculum development and implementation for Africa. Nsukka: Mike Social Press.

Ali, A. (1996). Fundamentals of Research in Education. Awka: Meks publishers Nig. Ltd

American Association for the Advancement of Science (1996). Benchmarks for science literacy. Cary, NC: American Association for the Advancement of Science

American Association for the Advancement of Science (2005). Benchmarks for Science literacy. New York: Oxford University Press

Borich, G.D (2011). Effective Teaching Methods, Research-Based Practice (7 $7^{\text {th }}$ ed.). New York: Pearson Education, Inc

Bozimo, G \& Ikwumelu, S.N. (2009). Social studies in a changing society. Owerri: Acadapeak publishers.

Byford, J. and Russell, W. (2006). Analyzing Public Issues-Clarification Through Discussion: A Case study of Social studies Teachers. Social studies Review, 46(1), 70-72

Chiodo, J. and Byford, J. (2006). Do they really dislike Social studies? A Study of middle school and high school students. Journal of Social studies Research, 28(1), 16-26.

Driscoll, M.P. (2005). Psychology of learning for instruction $\left(3^{r d}\right.$ ed). Boston, MA: Pearson

Fadeiye, J.O. (2005). A Social studies Textbookfor Colleges and Universities (part one). Ibadan: Akin Johnson press and publishers.

Hoagland, M (2000). Utilizing constructivism in the history classroom. Bloomington, In Eric clearinghouse for Social studies and Social Science Education, (Eric Production, ED415179).

Ellis, A., Fouts, J. and Glenn, A. (1992). Teaching and Lesrning Social studies. NewYork: Harper-collins press 
Ikwumelu, S.N. (2002). Relevance and functionality of Social studies Instructional materials and methodologies in Secondary Schools in Anambra State. An unpublished Ph.D thesis, University of Jos.

Ikwumelu, S.N. and Oyibe, O.A. (2011). Effective delivery of Social studies curriculum content for peace and cooperative living in Nigeria. Ebonyi State University Journal of Arts and Social Science Education, 2(1), 265-273

Jarolimek, J. (1977). Social studies in Elementary Education $\left(5^{\text {th }} \mathrm{ed}\right)$. New $\quad$ York: Macmillian Pub. Co. Inc.

Kelly, P.R. \& Farman, N. (1990). Practicing what we teach in reading education. Journal of readings 2 (4), 246-269

Leming, J.S., Ellington, L and Schug, M. (2006). The state of Social studies: A national random survey of elementary and middle school Social studies teachers. Social Education, 70 (5), 482-486

Mbakwem, J.N. (2001). Teaching and Learning: what principles? What methods? Owerri: Onii publishing House.

Mbakwem, J.N. (2005). Nigerian Social studies Teachers and Teaching resources: The shortfalls. Nigeria journal of curriculum studies. 12 (1), 163 - 169.

National Council for the Social studies (2002). National Standards for Social studies Teachers. Silver Springs. MD: National Council for the Social studies

National Council for the Social studies (2000). National Standards for Social studies Teachers. Washington D.C: National Council for the Social studies.

National Council of Teachers of English (2006). Guideline for the preparation of teachers of English language arts. Urbana, IL: National Council of Teachers of English.

National Council of Teachers of English (1996). Standards for the English Language Arts. Urbana, IL: National Council of Teachers of English.

National Council of Teachers of Mathematics (2005). Illustrating NCTM's Principles and Standards for school mathematics. Reston, AV: National Council of Teachers of Mathematics.

National Council of Teachers of Mathematics (2000). Principles and Standards for school mathematics. Reston, AV: National Council of Teachers of Mathematics.

National Council of Teachers of Mathematics (1995). Assessment Standards for school mathematics. Reston, AV: National Council of Teachers of Mathematics.

Oyibe, O.A and Mbang, E.B. (2013). Teachers' questioning skills in relation to students' achievement in Social studies. Journal of Research and Theory in Education, 5(2), 234-243 
Russell, W. and Byford, J. (2006). The evolution of man and his tools: A simulation from the MACOS project. Journal for the Liberal Arts \& Science. 10(3), 17-21.

Shaughnessy, J.M. and Haladyna, T.M. (1985). Research on students attitude towards Social studies. Social Education. 49 (2), 692- 695

Senesh, L. (2002). Teaching Economics through the problem solving approach. Journal of teaching Economics

Siler, C.R. (1998). Spital dynamic: An alternative teaching tool in the Social studies. Bloomington, In Eric clearinghouse for Social studies and Social Science Education, (Eric Production, ED415179).

Slavin, R.E. (1995). Cooperative learning among students: Theory, research and implication for active learning. $\underline{\text { http.www.scor.csos.hu.edu/statcorplear/h }}$

Stahl, R. (1994). Cooperative learning in Social studies: A Handbook for teachers (ed). New York: Addison-Wesley Publishing Company

Teo, N. (2006). Problem-based learning. In A. Ong \& G.D. Borich (ed), Teaching strategies that promote thinking. Singapore: McGraw-Hill

Vansledright, B. (2004). What does it mean to think historically....and how do you teach it? Social Education, 68(3), 230-233

Woolfolk, A. (2010). Educational Psychology (11 ${ }^{\text {th }}$ ed). Boston: Allyn \& Bacon 